\title{
PRODUCTION OF ORGANIC FERTILISERS AS A WAY TO IMPROVE ECONOMIC EFFICIENCY OF SMALL FARMS
}

\author{
Roman Uvarov, Alexander Briukhanov, Ekaterina Shalavina \\ Federal Scientific Agroengineering Centre VIM, Russia \\ rauvarov@gmail.com, sznii@yandex.ru, shalavinaev@mail.ru
}

\begin{abstract}
Russian agriculture is traditionally focused on large agro-industrial enterprises. However, currently, much is done to support small and medium-sized agri-businesses. By 2019, the share of peasant and small private farms reached $84 \%$ of the total output in certain agricultural sectors. Small businesses find it difficult to compete with large-scale farms due to the higher self-cost of their products. Organic production is a way to improve their market competitiveness. Aerobic solid-state fermentation of livestock waste makes it possible to produce highquality organic fertilisers, which can be applied in organic farming and marketed as a standalone product. Such waste processing is an affordable tool for small farms to reduce their negative impact on the environment. The feasibility study of the aerobic fermentation technology of solid organic waste in a drum bio-fermenter was conducted for a small private farm in the Chuvash Republic, Volga Federal District of Russia, with the recyclable material being a mixture of animal and poultry manure, chopped grass, sawdust and peat, and fermenter's productivity being $1 \mathrm{~m}^{3} \cdot \mathrm{day}^{-1}$. The study resulted in the following economic indicators: the capital costs of 21,110 EUR; the unit capital costs of 83 EUR $\cdot \mathrm{t}^{-1}$; the operating costs of $14,585 \mathrm{EUR} \cdot \mathrm{year}^{-1}$; the unit operating costs of 57 EUR $\cdot \mathrm{t}^{-1} \cdot$ year $^{-1}$; the labour inputs of $1.14 \mathrm{~h}$-hour $\cdot \mathrm{t}^{-1}$; and the energy inputs to produce the fertiliser of $27.0 \mathrm{~kW} \cdot \mathrm{t}^{-1}$. With the ready organic fertiliser's selling price being $144 \mathrm{EUR} \cdot \mathrm{t}^{-1}$, the payback period of this technology will be 1.53 years (or 18.5 months). Introduction of aerobic fermentation will reduce the nutrients loss by $0.69 \mathrm{t} \mathrm{N}^{\mathrm{N}} \mathrm{ear}^{-1}$ and $0.08 \mathrm{t} \mathrm{P}$ year $^{-1}$ against the passive composting.
\end{abstract}

Keywords: manure processing, organic fertiliser, economic efficiency, solid-state fermentation, bio-fermenter.

\section{Introduction}

Russian agriculture is traditionally focused on large agro-industrial enterprises. Following the global trends in agriculture and food systems, large-scale farms produce the bulk of domestic agricultural products [1]. However, the trend towards small businesses in the agro-industrial complex emerged in the early 2000s. Currently, they account for quite a significant output share in some livestock industries. At the same time, a certain grading is observed - the further south the region is located, the greater is the share of gross product produced by small farms (Fig. 1) [2-4].

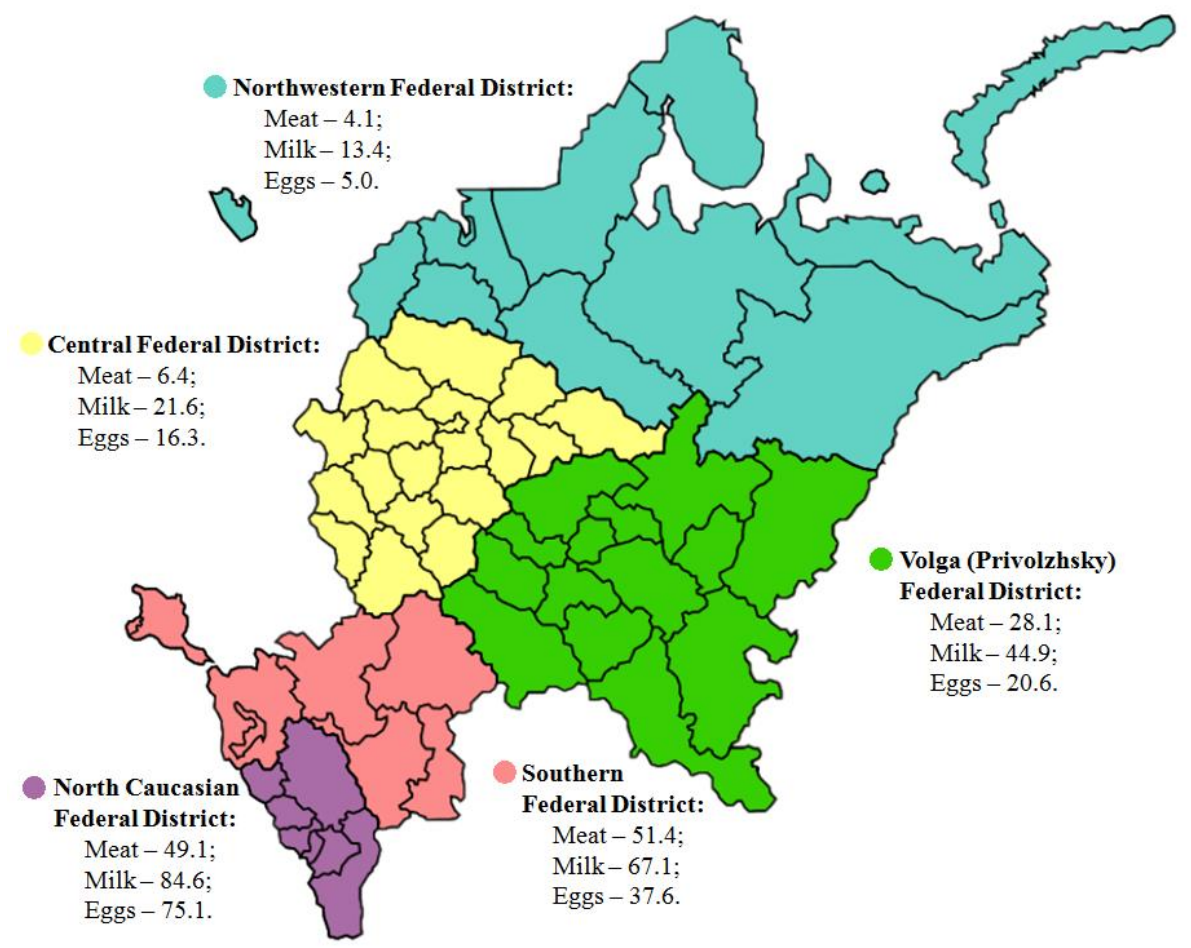

Fig. 1. Share of outputs produced by small farms in the European part of Russia (\%) 
Small farms do not have sufficient economic potential to compete with large agricultural enterprises. Therefore, they are forced to search for new ways to increase their economic efficiency. The transition to organic farming with a higher marketing value is a way to address this challenge. The application of organic fertilisers in crop rotations is among the major requirements of organic farming [5; 6]. The production of high-quality organic fertilisers from farm waste is also a tool of rational environmental management $[7 ; 8]$. It contributes to the mitigation of adverse environmental impact, lower greenhouse gas emissions, nutrients return to the processes of biogenesis and technogenesis, and improvement of soil fertility $[9 ; 10]$.

Small farms produce relatively small volumes of waste. They can introduce a relevant best available technique (BAT), which would best suit their specific climatic and economic conditions at lower costs compared with large agricultural enterprises. The Northern countries, Russia included, have a long cold period and a short time for produced fertiliser application. Therefore, preference should be given to farm waste processing technologies with minimal dependence on external weather conditions $[11 ; 12]$. Aerobic solid-state fermentation in closed-type bio-fermenters is one such technology. Drum-type biofermenters provide mixing and additional aeration of the processed material, thereby avoiding material compacting and the stagnant oxygen-free zones in some parts within the bio-fermenter. This guarantees highly stabile mesophilic and thermophilic processing modes and uniform compost maturing [13-15].

However, the key factor in decision-making on introducing the specific manure processing technology is its economic efficiency.

This study was focused on identifying the ecological and economic effects of organic fertiliser production on a small farm by aerobic solid-state fermentation.

\section{Materials and methods}

The feasibility study of the aerobic fermentation technology of solid organic waste in a drum biofermenter was conducted for a small private farm in the Chuvash Republic, Volga Federal District of Russia. The farm has 7 head of cattle, including 6 cows; 700 head of poultry: 450 chickens, 200 turkeys and 50 geese. The farm uses a bedding housing system: peat bedding for cattle and sawdust bedding for poultry. Daily manure output is $1 \mathrm{~m}^{3}$. day ${ }^{-1}$ or $0.7 \mathrm{t} \cdot \mathrm{day}^{-1}$ that is $365 \mathrm{~m}^{3} \cdot$ year $^{-1}$ or $255.5 \mathrm{t} \cdot \mathrm{year}^{-1}$. The type and quality of processed waste are shown in Table 1.

Table 1

Type and quality of processed waste

\begin{tabular}{|l|c|c|c|}
\hline \multicolumn{1}{|c|}{ Waste type } & $\begin{array}{c}\text { Mass, } \\
\mathbf{t} \cdot \mathbf{d a y}^{-\mathbf{1}}\end{array}$ & $\mathbf{N}_{\text {tot }}, \boldsymbol{\%}$ & $\mathbf{P}_{\text {tot }}, \boldsymbol{\%}$ \\
\hline Cattle manure & 0.35 & 3.0 & 1.8 \\
\hline Poultry manure & 0.21 & 3.6 & 3.4 \\
\hline Chopped grass, sawdust and peat & 0.14 & 1.0 & 0.6 \\
\hline Total & 0.70 & - & - \\
\hline
\end{tabular}

The drum bio-fermenter for waste processing with the productivity of $1 \mathrm{~m}^{3} \cdot \mathrm{day}^{-1}$ (Fig. 2) was placed outdoors in a heat-insulated container.

The following electrical equipment was installed in the bio-fermenter: drive of the loading device $(2.2 \mathrm{~kW})$; combined motor-reducer of the bio-fermenter drum drive $(1.5 \mathrm{~kW})$; drive of the unloading device $(2.2 \mathrm{~kW})$; forced-draught fan of the forced ventilation system $(1.5 \mathrm{~kW})$.

The bio-fermenter had the following specifications: installed capacity of $7.4 \mathrm{~kW}$, peak capacity of $5.2 \mathrm{~kW}$, daily energy consumption of $18.9 \mathrm{kWh}$ and one operator.

The economic efficiency of the production of solid organic fertilisers by aerobic solid-state fermentation was determined using the calculation methods specified in the Russian regulatory documents - Interstate Standard GOST 34393-2018. "Agricultural machinery. Methods of economic evaluation", Management Directive for Agro-Industrial Complex 1.10.15.02-17. "Recommended practice for engineering designing of systems for animal and poultry manure removal and preapplication treatment" and "Veterinary and sanitary rules associated with the preparation of animal and poultry manure and wastewater, produced under conditions of infectious and invasive diseases of 
animals and poultry, to be used as organic fertilisers" [16-18]. The economic effect was defined as the net profit of the small farm introducing this processing technology.

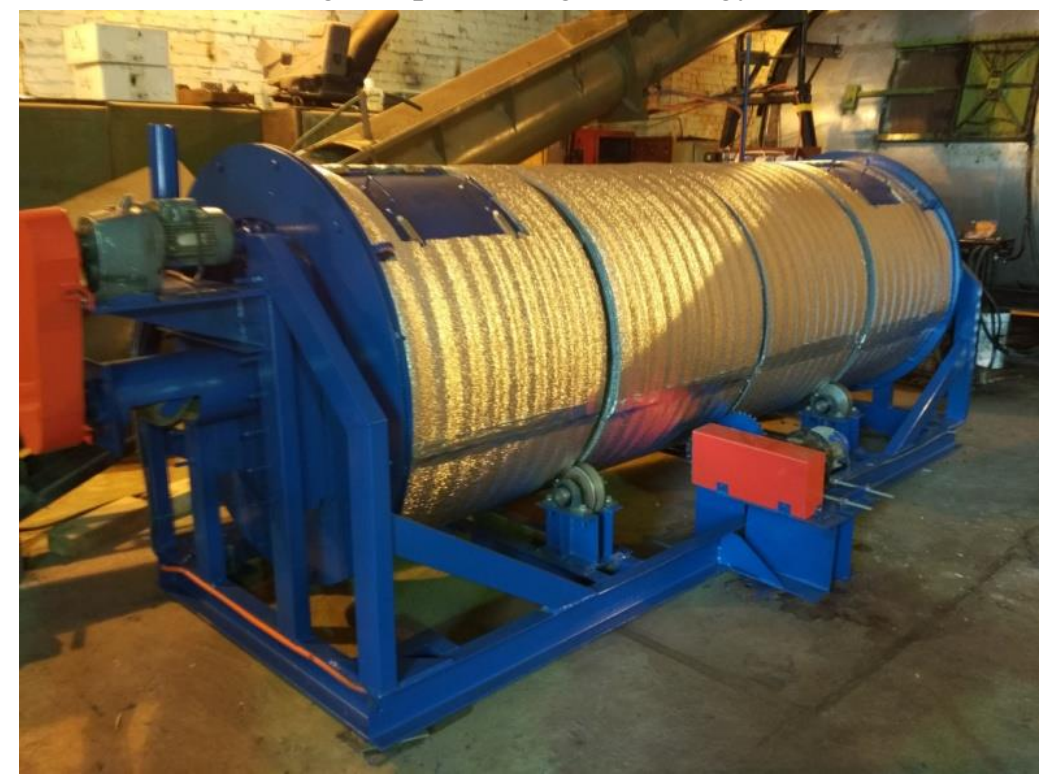

Fig. 2. Drum-type bio-fermenter

The obtained indicators were compared with the economic efficiency of solid organic fertiliser production by passive composting, which is the basic technology for organic waste utilisation in the Volga Federal District of Russia [19].

The environmental effect was calculated as the difference between the environmental pressure of passive composting and aerobic solid-phase fermentation in drum bio-fermenters in terms of nutrient loss reduction [20].

\section{Results and discussion}

The results of calculating the economic efficiency of solid organic fertiliser production by passive composting and aerobic solid-state fermentation are presented in Table 2. The equipment cost, overhead costs and wages are relevant for December 2020. The marketing cost of fertilisers is based on the average market price of such fertilisers in the Volga Federal District of Russia as of March 2021.

Table 2

\section{Economic efficiency of solid organic fertiliser production by passive composting} and aerobic solid-state fermentation (ASSF)

\begin{tabular}{|l|c|c|c|}
\hline \multicolumn{1}{|c|}{ Indicator } & Unit & Composting & ASSF \\
\hline Capital costs, including: & EUR & 18,890 & 21,110 \\
\hline unit capital costs & EUR $\cdot \mathrm{t}^{-1}$ & 74 & 83 \\
\hline Operating costs, including: & EUR $\cdot$ year $^{-1}$ & 17,783 & 14,585 \\
\hline depreciation & EUR $\cdot$ year $^{-1}$ & 822 & 1,778 \\
\hline maintenance and repairs of equipment & EUR $\cdot$ year $^{-1}$ & 517 & 1,653 \\
\hline fuel & EUR $\cdot$ year $^{-1}$ & 4,444 & - \\
\hline electricity & EUR $\cdot$ year $^{-1}$ & - & 514 \\
\hline wages & EUR $\cdot$ year $^{-1}$ & 12,000 & 8,000 \\
\hline packing & EUR $\cdot$ year $^{-1}$ & - & 418 \\
\hline transportation & EUR $\cdot$ year $^{-1}$ & - & 2,222 \\
\hline Unit operating costs (self-cost of produce) & EUR $\mathrm{t}^{-1} \cdot$ year $^{-1}$ & 70 & 57 \\
\hline Energy intensity of production & $\mathrm{kW} \cdot \mathrm{t}^{-1}$ & - & 27 \\
\hline Labour inputs & $\mathrm{h}-\mathrm{hour} \cdot \mathrm{t}^{-1}$ & 1.71 & 1.14 \\
\hline Fertiliser output & $\mathrm{t} \cdot$ year & \\
\hline Marketing cost of fertilisers & EUR $\cdot \mathrm{t}^{-1}$ & 212.1 & 196.7 \\
\hline
\end{tabular}


Table 2 (continued)

\begin{tabular}{|c|c|c|c|}
\hline Indicator & Unit & Composting & ASSF \\
\hline Revenue from sales & EUR·year-1 & 23,563 & 28,417 \\
\hline Profit on sales & EUR·year-1 & 5,779 & 13,832 \\
\hline Payback period & year & 3.27 & 1.53 \\
\hline
\end{tabular}

Our previous studies demonstrated that during the processing of the same type of waste by passive composting and aerobic solid-state fermentation, the nitrogen loss was $24.2 \%$ and $6.1 \%$ average, respectively, and the phosphorus loss was $5.7 \%$ and $0.8 \%$ average, respectively [21]. The nutrient content in the source and resulting materials is shown in Table 3.

Table 3

Nutrient content

\begin{tabular}{|c|c|c|c|c|}
\hline \multirow[t]{2}{*}{ Material } & \multicolumn{2}{|c|}{ Nutrient content } & \multicolumn{2}{|c|}{$\begin{array}{l}\text { Nutrient loss in respect to } \\
\text { source mixture }\end{array}$} \\
\hline & $N_{\text {tot }}, t_{\text {year }^{-1}}$ & $\mathbf{P}_{\text {tot }}$, t year $^{-1}$ & $N_{\text {tot }}, \mathrm{t}$ year $^{-1}$ & $P_{\text {tot }}$, t year $^{-1}$ \\
\hline Source mixture & 3.84 & 1.53 & - & - \\
\hline Compost after passive composting & 2.91 & 1.45 & 0.92 & 0.09 \\
\hline $\begin{array}{l}\text { Compost after aerobic } \\
\text { fermentation }\end{array}$ & 3.60 & 1.52 & 0.23 & 0.01 \\
\hline
\end{tabular}

The ecological effect of introducing aerobic fermentation instead of passive composting is expressed in lower nutrients loss $-0.69 \mathrm{t} \mathrm{N}$ year $^{-1}$ and $0.08 \mathrm{t} \mathrm{P}$ year $^{-1}$.

Waste recycling by aerobic solid-state fermentation improves the profitability of production owing to lower operating costs. The higher nutritional value of the resulting fertilisers owing to smaller nutrient loss is also a contributor in this respect.

The orientation of small farms towards entering the organic food sector is one of the global trends. Most farmers process the farm waste by composting [8; 22-24]. Some farmers, however, start applying more intensive and environmentally friendly utilisation technologies including aerobic solid-state fermentation $[25 ; 26]$. Relatively high capital costs for small farms are counterbalanced by lower operating costs, the possibility of waste processing in cold period and guaranteed disinfection of the material $[12 ; 27 ; 28]$. The resulting fertilisers have higher commercial quality, good particle size distribution and can be sold through trade networks [14;27].

The authors of [29] in two case studies in South Italy found the operating costs for the disposal of one ton of cattle manure to range from 9.9 to $31.5 \mathrm{EUR} \cdot \mathrm{t}^{-1} \cdot \mathrm{year}^{-1}$ depending on the animal housing system and the bedding material not including the employees' wages. The values from our study (23 EUR $\cdot \mathrm{t}^{-1} \cdot$ year $^{-1}$ for passive composting and $26 \mathrm{EUR} \cdot \mathrm{t}^{-1} \cdot \mathrm{year}^{-1}$ for aerobic solid-state fermentation) are near these findings. The wages of agricultural workers in Russia and Italy differ significantly. Therefore, the comparison of unit operating costs is not quite correct. In Italy, this indicator can reach 250 EUR $\cdot \mathrm{t}^{-1}$, while in Russia it is 70 EUR $\cdot \mathrm{t}^{-1}$ for passive composting and $57 \mathrm{EUR} \cdot \mathrm{t}^{-1}$ for aerobic solidstate fermentation. It would be more adequate for the Russian conditions to compare the obtained values with similar indicators during the upgrade of the waste management system on a large-scale farm: unit capital costs from 99.6 to 356.3 EUR $\cdot \mathrm{t}^{-1}$; unit operating costs from 38.1 to $115.0 \mathrm{EUR} \cdot \mathrm{t}^{-1} \cdot \mathrm{year}^{-1}$ [30].

\section{Conclusions}

1. The production of organic fertilisers, which can be used in organic farming and sold through trade networks, is a way to increase the profitability of agricultural enterprises. Introduction of an efficient and consistent with the principles of rational environmental management waste handling practice on small farms, for example, the aerobic solid-state fermentation, requires relatively small capital (74-83 EUR·t-1) and operational (57-70 EUR·t-1) investments.

2. In the study, the economic efficiency was calculated for a small farm with the waste output of $0.7 \mathrm{t}$ day-1 or $255.5 \mathrm{t}$ year-1. Two waste processing technologies were considered - passive composting and aerobic solid-state fermentation, and the payback period of 3.27 years and 1.53 years, respectively, was determined. 
3. The nutrient loss in aerobic solid-state fermentation was found to be 4 to 7 times smaller than that in passive composting. The ecological effect of introducing aerobic fermentation instead of passive composting was expressed in lower nutrient loss $-0.69 \mathrm{t} \mathrm{N}$ year- 1 and $0.08 \mathrm{t} \mathrm{P}$ year- 1 . Owing to the higher nutrient content, the resulting organic fertiliser contributes to more effective soil fertility improvement.

\section{References}

[1] Вегрен С., Троцук И. Устойчиво ли промышленное сельское хозяйство в условиях климатических изменений и экологических угроз? (Is industrial agriculture sustainable during climate change and ecological threats?). Journal of Economic Sociology: Экономическая социология, vol. 21 (5), 2020, pp. 12-38 (In Russian).

[2] Производство молока в хозяйствах всех категорий. Единая межведомственная информационно-статистическая система Федеральной службы государственной статистики. (Milk production in farms of all categories. Unified Interdepartmental Information-Statistical System (UIIS)). [online] [20.02.2021] Available at: https://fedstat.ru/indicator/40694 (In Russian).

[3] Производство скота и птицы на убой в живом весе в хозяйствах всех категорий. Единая межведомственная информационно-статистическая система Федеральной службы государственной статистики. (Production of cattle and poultry for slaughter in live weight in all categories of farms. Unified Interdepartmental Information-Statistical System (UIIS)). [online] [21.02.2021] Available at: https://fedstat.ru/indicator/31367 (In Russian).

[4] Производство яиц в хозяйствах всех категорий. Единая межведомственная информационностатистическая система Федеральной службы государственной статистики. (Egg production in farms of all categories. Unified Interdepartmental Information-Statistical System (UIIS)). [online] [21.02.2021] Available at: https://fedstat.ru/indicator/33946 (In Russian)

[5] Межгосударственный стандарт ГОСТ 33980-2016 "Продукция органического производства. Правила производства, переработки, маркировки и реализации" (Interstate Standard GOST 33980-2016 "Organic production. Regulations for production, processing, labelling and marketing”. Moscow: Standartinform: М.: Стандартинформ. 2020. 43 p. (In Russian).

[6] Minin V.B., Popov V.D., Maksimov D.A., et al. Developing of modern cultivation technology of organic potatoes. Agronomy Research, vol. 18 (S2), 2020, pp. 1359-1367.

[7] Petersen S.O., Sommer S.G., Béline F. et al. Recycling of livestock manure in a whole-farm perspective. Livestock Science, vol. 112 (3), 2007, pp. 180-191.

[8] Rufino M.C., Tittonell P., van Wijk M.T., et al. Manure as a key resource within smallholder farming systems: Analysing farm-scale nutrient cycling efficiencies with the NUANCES framework. Livestock Science, vol. 112 (3), 2007, pp. 273-287.

[9] Li Q., Wagan S.A., Wang Y. An analysis on determinants of farmers' willingness for resource utilization of livestock manure. Waste Management, vol. 120, 2021, pp. 708-715.

[10] Spiegal S., Kleinman P.J.A., Endale D.M., et al. Manure sheds: Advancing nutrient recycling in US agriculture. Agricultural Systems, vol. 182, 2020, 102813.

[11] Briukhanov A., Vasilev E., Kozlova N., et al. Environmental assessment of livestock farms in the context of BAT system introduction in Russia. Journal of Environmental Management, vol. 246, 2019, pp. 283-288.

[12] Miller S.R., Mann J.T., Leschewski A., et al. Survey of small Michigan livestock winter manure handling and economic assessment of policy change. 2017 ASABE Annual International Meeting. American Society of Agricultural and Biological Engineers, 2017, 1701423.

[13] Briukhanov A., Subbotin I., Uvarov R., et al. Method of designing of manure utilisation technology, Agronomy Research, vol. 15 (3), 2020, pp. 658-663.

[14] Uvarov R., Shalavina E., Briukhanov A., et al. Aerobic solid-state fermentation of the solid fraction of pig slurry. Agronomy Research, vol. 18 (S2), 2020, pp. 1537-1546.

[15] Timofeev E.V., Uvarov R.A., Erk A.F. Intellectualized control system of bio-fermenter. Ecology and Industry of Russia, vol. 24 (11), 2020, pp. 10-13.

[16] Межгосударственный стандарт ГОСТ 34393-2018 “Техника сельскохозяйственная. Методы экономической оценки" (Interstate Standard GOST 34393-2018. "Agricultural machinery. Methods of economic evaluation”). Moscow: Standartinform: М.: Стандартинформ. 2018. 15 p. (In Russian). 
[17] РД-АПК 1.10.15.02-17 Методические рекомендации по технологическому проектированию систем удаления и подготовки к использованию навоза и помёта (Management Directive for Agro-Industrial Complex 1.10.15.02-17. Recommended practice for engineering designing of systems for animal and poultry manure removal and pre-application treatment). Moscow: Rosinformagrotekh: М.: Росинфорагротех. 2017, 166 p. (In Russian).

[18] Ветеринарно-санитарными правилами подготовки к использованию в качестве органических удобрений навоза, помета и стоков при инфекционных и инвазионных болезнях животных и птицы (Veterinary and sanitary rules associated with the preparation of animal and poultry manure and wastewater, produced under conditions of infectious and invasive diseases of animals and poultry, to be used as organic fertilizers). Moscow: Yuridicheskaya Literatura Publishers: М.: Изд-во "Юридическая литература", 1997, 19 р. (in Russian).

[19] Абросимова М.С., Иванов Е.А., Кочергина С.Г. Состояние и направления развития сельского хозяйства региона [State and development trends in the region's agriculture]. Russian Journal of Entrepreneurship: Российское предпринимательство, vol. 19 (4), 2018, pp.977-990. (in Russian).

[20]Национальный стандарт РФ ГОСТ Р 54003-2010 “Экологический менеджмент. Оценка прошлого накопленного в местах дислокации организаций экологического ущерба. Общие положения" (Russian State Standard GOST R 54003-2010 "Ecological management. Evaluation of the past ecological damage accumulated in places of arrangement of organizations. General principles". Moscow: Standartinform: М.: Стандартинформ, 2019. 49 p. (In Russian).

[21] Uvarov, R., Briukhanov, A., Shalavina, E. Study results of mass and nutrient loss in technologies of different composting rate: Case of bedding poultry manure. Engineering for Rural Development, vol. 15, 2016, pp. 851-857.

[22] Case S.D.C., Oelofse M., Hou Y., et al. Farmer perceptions and use of organic waste products as fertilisers - A survey study of potential benefits and barriers. Agricultural Systems, vol. 151, 2017, pp. 84-95.

[23] Wang Y., Zhu Y., Zhang S., et al. What could promote farmers to replace chemical fertilizers with organic fertilizers? Journal of Cleaner Production, vol. 199, 2018, pp. 882-890.

[24] Idrovo-Novillo J., Gavilanes-Terán I., Angeles Bustamante M., et al. Composting as a method to recycle renewable plant resources back to the ornamental plant industry: Agronomic and economic assessment of composts. Process Safety and Environmental Protection, vol. 116, 2018, pp. 388395.

[25] Soccol C.R., da Costa E.S.F., Letti L.A.J. et al. Recent developments and innovations in solid state fermentation. Biotechnology Research and Innovation, vol. 1 (1), 2017, pp. 52-71.

[26] Fournel S., Godbout S., Ruel P. et al. Production of recycled manure solids for use as bedding in Canadian dairy farms: II. Composting methods. Journal of Dairy Science, vol. 102 (2), 2019, pp. 1847-1865.

[27] Uvarov, R., Briukhanov, A., Subbotin, I., et al. Disinfection of solid fraction of cattle manure in drum-type bio-fermenter. Agronomy Research, vol. 15 (3), 2017, pp. 915-920.

[28] Hsu E. Cost-benefit analysis for recycling of agricultural wastes in Taiwan. Waste Management, vol. 120, 2021, pp. 424-432.

[29] Pergola M., Piccolo A., Palese A.M. et al. A combined assessment of the energy, economic and environmental issues associated with on-farm manure composting processes: Two case studies in South of Italy. Journal of Cleaner Production, vol. 172, 2018, pp. 3969-3981.

[30] Uvarov R., Vasileva N., Vorobyeva E. Good manure management: Case study of dairy farm with loose housing system. Engineering for Rural Development, vol. 19, 2020, pp. 747-753. 